\title{
DEMONSTRASI MAHASISWA DI KOTA PEKANBARU BERDASARKAN UNDANG-UNDANG NOMOR 9 TAHUN 1998 TENTANG KEBEBASAN MENYAMPAIKAN PENDAPAT DI MUKA UMUM
}

\author{
Oleh: Andrizal \\ Dosen Fakultas Hukum Universitas Lancang Kuning \\ Alamat Kantor Jl. Yos Sudarso Km 8 Rumbai, Pekanbaru \\ Email:andrizal_rokan@gmail.com
}

\begin{abstract}
Abstrak
Demonstrasi mahasiswa dilakukan untuk menyampaikan pendapat atau gagasan dalam perbaikan kehidupan bermasyarakat karena dianggap tidak sesuai harapan. Dalam kenyataannya pelaksanaan demonstrasi dapat berujung menjadi anarkis dan tidak terkendali, meskipun telah ada aturan yang tegas. Artikel ini menganalisis pelaksanaan demonstrasi mahasiswa di Kota Pekanbaru berdasarkan UndangUndang Nomor 9 Tahun 1998 tentang Kebebasan Menyampaikan Pendapat di Muka Umum dengan menggunakan penelitian hukum sosiologis. Hasil analisis dalam artikel ini ditemukan fakta bahwa ketertiban mahasiswa berdemonstrasi di Kota Pekanbaru belum berjalan efektif menurut Undang-Undang Nomor 9 Tahun 1998. Mahasiswa cenderung tidak memberitahukan rencana aksi demonstrasi kepada pihak kepolisian, aksi demonstrasi mahasiswa melebihi batas waktu yang ditentukan peraturan perundang-undangan yang berlaku dan aksi demonstrasi mahasiswa berubah tidak tertib dan cenderung anarkis. Hambatan yang dihadapi dalam pelaksanaan demonstrasi karena adanya pembatasan waktu dalam menyampaikan pendapat di muka umum, aksi demonstrasi tidak mengikuti aturan pelaporan rencana aksi, pengamanan yang kasar yang tidak bertanggung jawab, intervensi dari pihak keamanan terutama intelijen, provokasi, pejabat atau sasaran aksi menghilang, kesalahpahaman antar massa aksi demonstrasi dengan pihak keamanan sehingga mengakibatkan konflik fisik, pengamanan aksi yang kasar, dan penghancuran/ penyitaan/perampasan alat peraga aksi. Upaya yang harus dilakukan dalam mengatasi beberapa hambatan itu adalah sosialisasi atau penyuluhan hukum Undang-Undang Nomor 9 Tahun 1998 tentang Kebebasan Menyampaikan Pendapat di Muka Umum kepada mahasiswa di Kota Pekanbaru agar mereka memahami substansi peraturan tersebut, pihak kepolisian harus memahami kondisi demonstrasi mahasiswa, pendanaan yang mencukupi, dan aturan hukum yang jelas dan mengikat.
\end{abstract}

\begin{abstract}
Student demonstrations performed to express opinions or ideas in the improvement of social life because they are not as expected. In fact, the implementation of demonstration can end up being anarchic and uncontrolled, despite strict rules. This article analyzes the implementation of a student demonstration in the city of Pekanbaru by Act No. 9 of 1998 on Freedom of Expression in Public by using sociological research. The results of the analysis in this article is found that the order of students demonstrated in the city of Pekanbaru has not been effective according to Law No. 9 of 1998. Students tend not tell plans to police demonstrations, demonstrations of students exceeding the prescribed time limit legislation that apply and student
\end{abstract}


demonstrations turned unruly and inclined anarchists. Obstacles encountered in the implementation of the demonstration because of the restriction of time in presenting their opinions in public, and demonstrations do not follow the rules of reporting the action plan, securing the rough is not responsible for the intervention of the security forces, especially intelligence, provocation, official or targeted by disappearing, misunderstandings between mass demonstrations by the security forces, resulting in a physical conflict, securing a rough action, and destruction / confiscation / expropriation action props. Efforts must be made to overcome some of the barriers it is socialization or legal counseling Law No. 9 of 1998 on Freedom of Expression in Public to students in the city of Pekanbaru so that they understand the substance of the regulation, the police must understand the conditions of the student demonstrations, funding sufficient and clear legal rules and binding.

\section{Kata kunci: Demonstrasi, Pendapat di Muka Umum, Mahasiswa}

\section{Pendahuluan}

Undang-Undang Nomor 9 Tahun 1998 mengatur tentang Kemerdekaan Menyampaikan Pendapat di Muka Umum. Pasal 3 undangundang tersebut menyatakan bahwa pelaksanaannya harus memenuhi beberapa asas, yakni asas keseimbangan antara hak dan kewajiban, asas musyawarah dan mufakat, asas kepastian hukum dan keadilan, asas proporsionalitas, dan asas manfaat. Asasasas ini menjadi landasan kebebasan yang bertanggung jawab dalam penyampaikan pendapat di muka umum.

Pemberlakuan undang-undang tersebut tidak menjamin pelaksanaan demonstrasi menjadi tertib. Dalam praktiknya sering terjadi unjuk rasa yang tidak dapat dikendalikan dan berujung pada tindak kekerasan serta kerusuhan massa yang menganggu ketertiban umum seperti dalam kasus Trisakti, Kasus Universitas Nasional (Unas) dan sebagainya.

Kerusuhan massa dapat terjadi dengan 5 (lima) prasyarat (determinan) yang secara bertahap harus dipenuhi, yaitu situasi sosial yang memungkinkan timbulnya kerusuhan, tekanan sosial, berkembangnya prasangka kebencian yang meluas terhadap suatu sasaran tertentu, mobilisasi massa untuk beraksi, dan kontrol sosial yang dikendalikan oleh aparat keamanan. ${ }^{1}$ Kelima determinan ini dapat diantisipasi dengan baik untuk menghindari kerusuhan massa.

Demonstrasi dapat dilakukan dengan pikiran dengan lisan, tulisan dan sebagainya secara demonstratif di muka umum yang dilakukan secara tertib atau tidak. Bentuk saluran-saluran/ruang terbuka baik secara formal melalui Dewan Perwakilan Rakyat (DRD)/Dewan Perwakilan Rakyat Daerah (DPRD). Namun, maraknya penyampaian pendapat di muka umum dengan aksi unjuk rasa turun ke jalan lebih disukai oleh masyarakat dalam mengemukakan tuntutan/aspirasi.

Kemerdekaan menyampaikan pendapat di muka umum merupakan hak asasi manusia yang dijamin oleh Undang-Undang Dasar Negara Republik Indonesia Tahun 1945 dan Deklarasi Universal Hak-hak Asasi. Penyampaian pendapat di muka umum merupakan perwujudan demokrasi dalam tatanan kehidupan bermasyarakat, berbangsa dan bernegara. Dalam kaitannya dengan upaya membangun suatu negara demokrasi diperlukan juga adanya suasana yang aman,

${ }^{1}$ N.J. Smelser, Theory of Collective Behaviour, (Jakarta: Yayasan Obor, 2000), hlm. 273. 
tertib dan damai dengan tidak merugikan kepentingan dan hak asasi manusia yang lainnya. ${ }^{2}$

Dalam hal pengamanan terhadap unjuk rasa, diberlakukan Undang-Undang Nomor 2 Tahun 2002 tentang Kepolisian Republik Indonesia berimplikasi pada adanya perubahan paradigma Polri. Polri dituntut untuk tidak lagi mengedepankan tindakan represif melainkan tindakan persuasif dan preventif. Tugas pokok dan wewenang Polri sebagaimana disebutkan dalam Pasal 13 Undang-Undang Nomor 2 Tahun 2002 tentang Polisi Republik Indonesia diantaranya: a. Memelihara keamanan dan ketertiban masyarakat. b. Menegakkan hukum. c. Memberikan perlindungan, pengayoman dan pelayanan kepada masyarakat. Demonstrasi dapat dikatakan aman, tertib dan damai jika proses pelaksanaannya tidak menimbulkan peristiwa atau kegiatan yang melanggar aturan hukum yang berlaku dan tidak menimbulkan tindakan yang dapat mengganggu keamanan dan keteriban masyarakat.

Lembaga Kepolisian telah menyiapkan langkah-langkah pengamanan dengan dikeluarkannya Surat Keputusan Kapolri Nomor Pol: Skep/1600/X/1998 dan Surat Keputusan Direktur Samapta Babinkam Polri Nomor Polisi: Proptap/01/V/2004. Pengamanan demonstrasi yang dilakukan oleh Polri tidak sekedar mengamankan tempat dan pengunjuk rasa saja, tetapi lebih dari itu mengamankan lingkungan masyarakat secara umum.

Tata cara pelaksanaan penyampai pendapat di muka sebetulnya telah diatur secara tegas, namun dalam praktik ketentuan tersebut banyak yang tidak dipenuhi/dilanggar oleh peserta aksi demonstrasi, misalnya tidak terpenuhinya waktu pemberitahuan, tidak memberitahukan kepada Polisi setempat, kegiatan unjuk rasa tidak sesuai dengan surat pemberitahuan (baik dari rute, waktu, lama, alat peraga yang dibawa maupun jumlah peserta).

Berdasarkan pengamatan yang penulis lakukan pelaksanaan domonstrasi mahasiswa di Kota Pekanbaru belum sesuai dengan ketentuan yang terdapat dalam UndangUndang Nomor 9 Tahun 1998 yang cenderung berakibat jalanan macet, rusuh, anarkis, dan sebagainya seperti dalam demonstrasi kenaikan Bahan Bakar Minyak (BBM) dan Pemilihan Kepala Daerah (Pilkada). Permasalahan inilah yang mendorong peneliti untuk melakukan penelitian dengan rumusan permasalahan: 1. Bagaimanakah ketertiban mahasiswa berdemonstrasi di Kota Pekanbaru menurut Undang-Undang Nomor 9 Tahun 1998 tentang Kebebasan Menyampaikan Pendapat di Muka Umum? 2. Apakah hambatan yang dihadapi mahasiswa berdemonstrasi di Kota Pekanbaru menurut Undang-Undang Nomor 9 Tahun 1998 tentang Kebebasan Menyampaikan Pendapat di Muka Umum? 3. Apakah upaya yang harus dilakukan mahasiswa dalam berdemonstrasi di Kota Pekanbaru menurut Undang-Undang Nomor 9 Tahun 1998 tentang Kebebasan Menyampaikan Pendapat di Muka Umum?

\section{Metode Penelitian}

Jenis penelitian ini merupakan penelitian hukum sosiologis dengan lokasi penelitian di Kota Pekanbaru. Alasan penetapan lokasi didasarkan atas pertimbangan bahwa Kota Pekanbaru merupakan kota yang paling sering terjadi demonstrasi mahasiswa dibandingkan kabupaten/kota yang terdapat di Provinsi Riau. Sampel penelitian yang ditetapkan adalah Kaur Bin Ops Sat Intelkam Polresta Pekanbaru berjumlah 1 orang, Pengurus BEM universitas

${ }^{2}$ Sri Handayani, Implementasi Undang-Undang Nomor 9 Tahun 1998 tentang Kemerdekaan Menyampaikan Pendapat di Muka Umum di Wilayah Sragen, (Surakarta: Tesis Pascasarjana IImu Hukum Universitas Sebelas Maret, 2008), hIm 117. 
negeri dan universitas swasta di Kota Pekanbaru berjumlah 1 orang pada masingmasing universitas terdiri atas (Universitas Riau, Universitas Lancang Kuning, Universitas Islam Negeri Sultan Syarif Qasim, Universitas Islam Riau), Ketua Persatuan Wartawan Indonesia Kota Pekanbaru berjumlah 1 orang, dan Ketua/Anggota Komisi 1 Dewan Perwakilan Rakyat Daerah Kota Pekanbaru berjumlah 1 orang.

Data dalam penelitian ini terdiri atas 1) data primer, yakni data yang diperoleh dari lapangan yang telah ditetapkan dalam sampel, 2) data sekunder, yakni data yang diperoleh melalui beberapa literatur-literatur dan berbagai peraturan perundang-undangan, dan 3) data tertier, yaitu data yang diperoleh melalui kamus dan eksiklopedi. Teknik pengumpulan data dalam penelitian ini menggunakan observasi dengan cara pengamatan langsung terhadap obyek penelitian, wawancara terhadap responden, dan kajian kepustakaan menganalisis berbagai literatur kepustakaan yang memiliki korelasi dengan permasalahan yang sedang diteliti.

Analisis data menggunakan analisis kualitatif dengan menguraikan secara deskriptif dari data yang telah diperoleh. Penyimpulan hasil penelitian menggunakan metode induktif tentang aspek hukum pelaksanaan demonstrasi mahasiswa Kota Pekanbaru. Metode induktif adalah menarik suatu kesimpulan suatu pernyataan atau dalil yang bersifat khusus menjadi suatu pernyataan atau dalil yang bersifat umum.

\section{Pembahasan}

\section{Substansi Demonstrasi Sebagai Penyam- paian Gagasan}

Demonstrasi adalah suatu gerakan protes dengan cara turun ke jalan. Demonstrasi berasal dari dua suku kata, yaitu kata demo (unjuk rasa) dan kata konsentrasi (pemusatan perhatian atau pikiran pada suatu hal, atau pemusatan tenaga, kekuatan, pasukan, dan sebagainya di suatu tempat) melebur menjadi satu kata tunggal, yakni demonstrasi. ${ }^{3}$ Demonstrasi dapat juga diartikan sebagai suatu aksi dalam bentuk unjuk rasa yang dilakukan dengan pemusatan suatu isu. ${ }^{4}$

Demonstrasi merupakan pilihan wajar dan bahkan dapat menjadi pilihan satu-satunya untuk mengungkapkan aspirasi yang tersumbat oleh sistem maupun oleh mentalitas para pejabat negara dalam iklim demokrasi saat ini. Oleh karena itu, tidak ada jaminan bahwa unjuk rasa akan hilang dengan sendirinya manakala sistem telah ditata sedemikian rupa. Sebab, tarik-menarik kepentingan akan selalu menghiasi kehidupan berbangsa dan bernegara. Di samping juga, demonstrasi dapat menjadi alat kontrol terhadap kekuasaan, yakni sebagai kekuatan check and balance, sebagai kekuatan pengimbang, agar tidak terjadi ketimpangan yang destruktif. ${ }^{5}$

Konstitusi sangat menghormati dan memberi tempat yang layak bagi masyarakat yang ingin melakukan demonstrasi di ruang publik. ${ }^{6}$ Tindak lanjut dari konstitusi tersebut lebih dituangkan dalam aturan setingkat undang-undang, yaitu Undang-Undang Nomor

${ }^{3}$ Badan Pengembangan dan Pembianaan Bahasa, Kamus Besar Bahasa Indonesia, (Jakarta: Balai Pustaka, 2007), hlm. 306.

${ }^{4}$ Anugrah Purnamasari S, Kajian Spasial Ruang Publik (Public Space) Perkotaan Untuk Aktivitas Demonstrasi Mahasiswa di Kota Makassar, Jurnal Bumi Indonesia, Volume 1, Nomor 2, Tahun 2012, hlm. 28.

${ }^{5}$ Muhammad Gazali Rahman, Unjuk Rasa Versus Menghujat (Analisis Deskiptif Melalui Pendekatan Hukum Islam), Jurnal Studia Islamika, Volume 12, Nomor 2, Desember 2015, hlm. 349.

${ }^{6}$ Tri Pranadji, Aksi Unjuk Rasa (dan Radikalisme) Serta Penangannya Dalam Alam Demokrasi di Indonesia, Jurnal Forum Penelitian Agro Ekonomi, Volume 26, Nomor 2, Desember 2008, hlm. 137. 
9 Tahun 1998 tentang Kemerdekaan Menyampaikan Pendapat di Muka Umum.

Pasal 1 Ayat (2) Undang-Undang Nomor

9 Tahun 1998 tentang Kemerdekaan Menyampaikan Pendapat di Muka Umum mendefinisikan bahwa demonstrasi adalah kegiatan yang dilakukan oleh seorang atau lebih untuk mengeluarkan pikiran. Demonstrasi merupakan sebuah media dan sarana penyampaian gagasan atau ide-ide yang dianggap benar dan berupaya mempublikasikannya dalam bentuk pengarahan massa. Demonstrasi juga merupakan sebuah sarana atau alat sangat terkait dengan tujuan digunakannya sarana atau alat tersebut dan cara penggunaannya.

Demonstrasi merupakan tindakan untuk menyampaikan penolakan, kritik, ketidakberpihakan, dan penolakan terhadap hal-hal yang dianggap sebuah penyimpangan. Demonstrasi tidak sesempit yang dipahami oleh sebagian besar masyarakat dengan melakukan long-march, berteriak-teriak, membakar ban, aksi teatrikal, merusak pagar, atau tindakan-tindakan yang selama ini melekat pada kata demonstrasi. Tempatnya ruang terbuka publik yang dapat dilihat oleh publik secara umum atau terang-terangan. ${ }^{7}$

Demonstrasi dapat bernilai positif, namun dapat juga bernilai negatif. Ketika demonstrasi itu menjunjung tinggi demokrasi maka dipandang sebagai hal positif dan mempunyai nilai di mata masyarakat. Namun, ketika demonstrasi mengabaikan demokrasi maka dipandang sebagai hal yang negatif. Demonstrasi merupakan cara menyampaikan pikiran atau pendapat yang harus dijaga dan dipelihara agar tidak berubah menjadi tujuan yang negatif. ${ }^{8}$

Penyampaian pendapat di muka umum harus dilaksanakan sesuai beberapa asas dalam Pasal 3 Undang-Undang Nomor 9 Tahun 1998 tentang Kemerdekaan Menyampaikan Pendapat di Muka Umum: 1) Asas keseimbangan antara hak dan kewajiban; 2) Asas musyawarah dan mufakat; 3) Asas kepastian hukum dan keadilan; 4) Asas proporsionalitas; dan 5) Asas manfaat. Kelima asas ini merupakan landasan kebebasan yang bertanggung jawab dalam berpikir dan bertindak untuk menyampaikan pendapat di muka umum.

\section{Perlindungan Hukum Terhadap Kebebasan Menyampaikan Pendapat di Muka Umum}

Kebebasan menyampaikan pendapat di muka umum dijamin dalam Undang-Undang Dasar 1945 Pasal 28, 28 EAyat (3), Ketetapan Majelis Permusyawaratan Rakyat (MPR) Republik Indonesia No. XVSII/MPR/1998 tentang Hak Asasi Manusia Pasal 14, 19, 20, dan 21, Deklarasi Universal Hak-hak Asasi Manusia Pasal 19, Undang-Undang Nomor 9 Tahun 1998 tentang Kemerdekaan Menyampaikan Pendapat di Muka umum dan Undang-Undang Nomor 39 Tahun 1999 tentang Hak Asasi Manusia Pasal 14, 23 Ayat (2) dan Pasal 25.

Demonstrasi atau unjuk rasa termasuk dalam hak asasi manusia yang harus dilindungi. Dalam batang tubuh Undang-Undang Dasar 1945, dijabarkan prinsip-prinsip hak asasi manusia, seperti: ${ }^{9}$

\footnotetext{
${ }^{7}$ Bobby Savero, Demonstrasi: Perjuangan Konstektual (Online). Artikel Tahun 2008, http:// www.wikimu.com/New/DisplayNews.aspx?id=8449,diakses tanggal 12 Mei 2015.

${ }^{8}$ Daniel Simamora, Analisis Pertanggungjawaban Pidana Pelaku Unjuk Rasa yang Bersifat Anarki (Studi Putusan Nomor: 2.156/Pid.B/2009/PN.Mdn), (Medan: Universitas Sumatera Utara, 2010), hlm. 26.

${ }^{9}$ Darwan Prinst, Sosialisasi \& Diseminasi Penegakan Hak Asasi Manusia, (Bandung: Citra Aditya Bakti, 2001), hlm. 2.
} 
“1. Persamaan kedudukan warga negara dalam hukum dan pemerintahan (Pasal 27 Ayat (1).

2. Hak atas pekerjaan dan penghidupan yang layak (Pasal 27 Ayat (2).

3. Kemerdekaan berserikat dan berkumpul (Pasal 28).

4. Hak mengeluarkan pikiran dengan lisan atau tulisan (Pasal 28).

5. Kebebasan memeluk agama dan beribadat sesuai dengan agama dan kepercayaannya itu (Pasal 29 Ayat (2)).

6. Hak memperoleh pendidikan dan pengajaran (Pasal 31 Ayat (1)".

Demonstrasi atau aksi unjuk rasa merupakan salah satu bentuk penyampaian pendapat yang dilakukan di muka umum dan bagian dari perwujudan demokrasi yang dianut bangsa Indonesia. Demonstrasi merupakan sebuah media dan sarana penyampaian gagasan atau ide-ide yang dianggap benar dan berupaya mempublikasikannya dalam bentuk pengarahan massa. Demonstrasi juga merupakan sebuah sarana atau alat sangat terkait dengan tujuan digunakannya sarana atau alat tersebut dan cara penggunaannya.

Unjuk rasa atau demokrasi dipandang sebagai bentuk tingkah laku agresif, khususnya tingkah laku agresif massa yang timbul sebagai akibat adanya frustasi di masyarakat yang terjadi karena adanya ketidaksesuaian antara harapan yang wajar dengan kenyataan yang didapatkan (relative deprivation). Selain itu, unjuk rasa dipandang sebagai tindakan kolektif yang didalamnya terdapat beberapa kelompok manusia yang sangat potensial dan mudah diajak untuk melakukan unjuk rasa, diantaranya orang miskin, orang yang sedang mengalami frustasi, orang yang tidak puas, orang yang tersingkir, kelompok usia muda, juga kelompok marginal di tengah masyarakat. ${ }^{10}$

Demonstrasi harus dilakukan dengan damai dan tidak mengganggu ketertiban umum, sehingga yang disampaikan dapat didengar khalayak umum baik masyarakat, penguasa, pejabat, dan elit politik negara. Demonstrasi yang berkembang dan terjadi diberbagai daerah baik yang dilakukan oleh masyarakat, Lembaga Swadaya Masyarakat, Organisasi Kemasyarakatan, Partai Politik, dan mahasiswa seringkali berujung anarkis dan ricuh.

Demonstrasi dapat menjadi pencerahan terhadap permasalahan yang berkembang dengan mengusung suara aspirasi yang kritis, aspiratif, dan solutif yang mewakili seluruh keinginan dan harapan bersama untuk sebuah kemajuan dan kebaikan negara. Namun, demonstrasi pada saat ini terjadi di luar harapan masyarakat. Demonstrasi tidak lagi memberikan solusi, tetapi justru membawa problem baru.

Demonstrasi yang dilakukan oleh beberapa mahasiswa baik perguruan tinggi negeri maupun perguruan tinggi swasta cenderung tidak tertib dan menjurus anarkis. Kenyataan ini merupakan preseden buruk dan kontra produktif terhadap visi perjuangan para demonstran karena merugikan berbagai pihak. Kondisi ini terlihat dari sikap anarkis massa yang merusak berbagai sarana prasarana dan menggangu ketertiban umum, seperti memblokade jalan yang menggangu pengendara umum, membakar ban bekas, membentangkan spanduk, foto-foto, bendera, merusak pagar, dan berbagai fasilitas umum lainnya.

\footnotetext{
${ }^{10}$ Eric Hoffer, Gerakan Massa, ter. Masri Maris, (Jakarta: Yayasan Obor. 1992), hlm. 26.
} 
Pelaksanaan Demonstrasi Mahasiswa Kota Pekanbaru Ditinjau Dari Undang-Undang Nomor 9 Tahun 1998 tentang Kemerdekaan Menyampaikan Pendapat di Muka Umum

Kebebasan berpendapat dijamin pada dasarnya dalam konstitusi dan peraturan perundangan-undangan yang berlaku. Demonstrasi sebagai perwujudan kebebasan berpendapat merupakan salah satu hak asasi manusia ${ }^{11}$ yang diatur dalam Undang-Undang Nomor 9 Tahun 1998 tentang Kemerdekaan Menyampaikan Pendapat di Muka Umum. Dalam undang-undang itu diatur mengenai bentuk-bentuk dan tata cara penyampaian pendapat di muka umum.

Pasal 9 Ayat (1) Undang-Undang Nomor 9 Tahun 1998 itu menyatakan bahwa bentuk penyampaian pendapat di muka umum dapat dilaksanakan dengan a. Unjuk rasa atau demonstrasi; b. Pawai; c. Rapat umum; dan/ atau d. Mimbar bebas. Selanjutnya, Pasal 9 Ayat (2) pada undang-undang yang sama menyatakan bahwa penyampaian pendapat di muka umum sebagaimana dimaksud dalam Ayat (1), dilaksanakan ditempat-tempat terbuka untuk umum, kecuali: a. di lingkungan istana kepresidenan, tempat ibadah, instalasi militer, rumah sakit, pelabuhan udara atau laut, stasiun kereta api, terminal angkutan darat. b. objekobjek vital nasional. c. pada hari besar nasional. Pada 9Ayat (3) menyatakan bahwa pelaku atau peserta penyampaian pendapat di muka umum sebagaimana dimaksud dalam Ayat (1) dilarang membawa benda-benda yang dapat membahayakan keselamatan umum.

Pasal 10 Ayat (1) Undang-Undang Nomor 9 Tahun 1998 tentang Kemerdekaan Menyampaikan Pendapat di Muka Umum menyatakan bahwa penyampaian pendapat di muka umum sebagaimana dimaksud dalam
Pasal 9 wajib diberitahukan secara tertulis kepada Polri. Pasal 10 Ayat (2) menyatakan bahwa pemberitahuan secara tertulis sebagaimana dimaksud dalam Ayat (1), disampaikan oleh yang bersangkutan, pemimpin, atau penanggung jawab kelompok. Pada Pasal 10Ayat (3) Undang-Undang Nomor 9 Tahun 1998 tentang Kemerdekaan Menyampaikan Pendapat di Muka Umum menyatakan bahwa Pemberitahuan sebagaimana dimaksud dalam Ayat (1) selambatlambatnya 3 x 24 jam sebelum kegiatan dimulai telah diterima oleh pihak kepolisian setempat. Pasal 10 Ayat (4) menyatakan bahwa pemberitahuan secara tertulis sebagaimana dimaksud dalam Ayat (1) tidak berlaku bagi kegiatan ilmiah di dalam kampus dan kegiatan keagamaan.

Pasal 11 Undang-Undang Nomor 9 Tahun 1998 tentang Kemerdekaan Menyampaikan Pendapat di Muka Umum menyatakan bahwa "Surat pemberitahuan sebagaimana dimaksud dalam Pasal 10 Ayat (1) memuat a. maksud dan tujuan; b. tempat, lokasi dan rute; c. waktu dan lama; d. Bentuk; e. penanggung jawab; f. nama dan alamat organisasi, kelompok atau perseorangan; g. alat peraga yang digunakan; dan/atau h. jumlah peserta.

Pasal 12 Ayat (1) Undang-Undang Nomor 9 Tahun 1998 tentang Kemerdekaan Menyampaikan Pendapat di Muka Umum menyatakan bahwa penanggungjawab kegiatan sebagaimana dimaksud dalam Pasal 6, Pasal 9, dan Pasal 11 wajib bertanggung jawab agar kegiatan tersebut terlaksana secara aman, tertib dan aman. Pada Pasal 12 Ayat (2) menyatakan bahwa setiap sampai 100 (seratus) orang pelaku atau peserta unjuk rasa atau demonstrasi dan pawai harus ada seorang sampai dengan lima orang penanggung jawab.

${ }^{11}$ I Gede Pasek Eka Wisanjaya, Hak Menyatakan Pendapat di Muka Umum Secara Bebas dan Bertanggung jawab, Jurnal Hukum Udayana, Volume 2, Nomor 1, 2013, hlm. 79. 
Berdasarkan hasil wawancara menunjukkan bahwa pelaksanaan demonstrasi mahasiswa Kota Pekanbaru belum sesuai dengan Undang-Undang Nomor 9 Tahun 1998 tentang Kemerdekaan Menyampaikan Pendapat di Muka Umum. Pada umumnya peserta kegiatan demonstrasi tidak memahami tata aturan yang telah diatur dalam undangundang tersebut.

Hotman Sitompul selaku Anggota Komisi 1 Dewan Perwakilan Rakyat Daerah (DPRD) Kota Pekanbaru berpendapat bahwa "sangat setuju adanya persyaratan dan prosedur tertentu demonstrasi atau unjuk rasa. la beralasan bahwa agar demonstrasi dapat berjalan dengan tertib". ${ }^{12}$ Asril Darma selaku Ketua Persatuan Wartawan Indonesia (PWI) Kota Pekanbaru menyatakan bahwa "kurang memahami yang dimaksud dengan prosedur tertentu untuk unjuk rasa mahasiswa, undang-undang yang berlaku seharusnya bersifat universal (umum) untuk semua kalangan". ${ }^{13}$

Raja Kosmos Parmulais, Kepala Urusan Pembinaan Operasi (Kaur Bin Ops Sat) Intelkam Polresta Pekanbaru menjelaskan "adanya prosedur tertentu untuk melaksanakan demonstrasi. Menurutnya demonstrasi merupakan hak setiap warga negara dan telah dilindungi kebebasan tersebut dalam undangundang. Namun, adanya prosedur tertentu yang terdapat dalam undang-undang bertujuan untuk pembatasan hak agar tidak merugikan atau melanggar hak orang lain". ${ }^{14}$

Berkenaan dengan adanya pengaturan bentuk, tata cara, dan tanggung jawab pelaksanaan penyampaian pendapat di muka umum yang termaktub dalam Undang-Undang Nomor 9 Tahun 1998 tentang Kemerdekaan Menyampaikan Pendapat di Muka Umum, responden setuju adanya pengaturan tersebut. Hanya saja peserta kegiatan tampaknya banyak yang mematuhi aturan-aturan yang ada.

Said Firdaus, Menteri Sosial dan Politik Badan Eksekutif Mahasiswa (BEM) Universitas Islam Negeri Sultan Syarif Kasim Pekanbaru menyambut baik adanya pengaturan mengenai demonstrasi. Menurut Said Firdaus, "adanya pengaturan tersebut bertujuan agar setiap aksi demonstrasi berjalan dengan baik dan teratur". ${ }^{15}$

Selama ini banyak aksi demonstrasi mahasiswa yang berjalan anarkis. Namun, pengaturan tersebut tidak boleh mengekang mahasiswa dalam melakukan aksi demonstrasi. Muhammad Syarif selaku Sekretaris Kabinet Badan Eksekutif Mahasiswa (BEM) Universitas Islam Riau mengemukakan bahwa "selama pengaturan itu tidak berat sebelah dan untuk kebaikan bersama maka perlu disambut dengan baik dan memberikan apresiasi terhadap pengaturan tersebut. Sebab, pengaturan tersebut akan mengarahkan aksi demonstrasi menjadi lebih baik". ${ }^{16}$

\footnotetext{
${ }^{12}$ Hasil wawancara dengan Hotman Sitompul pada 6 Mei 2015 di kantor DPRD Kota Pekanbaru.

${ }^{13}$ Hasil wawancara dengan Ketua Persatuan Wartawan Indonesia (PWI) Kota Pekanbaru pada hari Senin, tanggal 11 Mei 2015, jam 10.00 Wib., di Kantor PWI Kota Pekanbaru.

${ }^{14} \mathrm{Hasil}$ wawancara dengan Raja Kosmos Parmulais pada hari Rabu, tanggal 06 Mei 2015, jam 14.00 WIB di Polresta Pekanbaru.

${ }^{15}$ Hasil wawancara dengan Said Firdaus, Menteri Sosial dan Politik Badan Eksekutif Mahasiswa (BEM) Universitas Islam Negeri Sultan Syarif Kasim Pekanbaru pada hari Senin, tanggal 4 Mei 2015, jam 9.00 Wib, di kantor BEM Universitas Islam Negeri Sultan Syarif Kasim Pekanbaru.

${ }^{16}$ Hasil wawancara Muhammad Syarif selaku Sekretaris Kabinet Badan Eksekutif Mahasiswa (BEM) Universitas Islam Riau pada hari Jum'at, tanggal 08 Mei 2015, jam 15.00 Wib, di Kantor BEM Universitas Islam Riau.
} 
Hotman Sitompul sangat setuju dengan adanya pengaturan untuk penyampaian pendapat di muka umum yang terdapat dalam Undang-Undang Nomor 9 Tahun 1998 tentang Kemerdekaan Menyampaikan Pendapat di Muka Umum. Hotman Sitompul beralasan bahwa "agar pelaksanaan penyampaian pendapat di muka umum akan lebih teratur dan terarah. DPRD Kota Pekanbaru seharusnya dapat memantau efektifitas pelaksanaan peraturan tersebut. Selama peserta kegiatan melakukan prosedur yang diatur dalam undangundang maka pelaksanaan demonstrasi pasti dapat berjalan dengan baik, sehingga gagasan mahasiswa dapat disampaikan dan masyarakat dapat menerima aksi tersebut dengan nilai positif". ${ }^{17}$

Demonstrasi mahasiswa tentu saja menghormati hak-hak orang lain, menghormati aturan moral yang diakui umum, menaati hukum yang berlaku dan menjaga keamanan dan ketertiban umum. ${ }^{18}$ Kedewasaan mahasiswa sebetulnya dapat dilihat dalam kegiatan yang dilaksanakan itu terencana dengan baik atau tidak. Demonstrasi sebagai cara dalam menyampaikan pendapat, tentu mahasiswa harus taat pada aturan yang ada, agar demonstrasi dapat memberikan manfaat. ${ }^{19}$ Sejalan dengan Ali Akbar, Muhammad Syarif, Sekretaris kabinet Badan Eksekutif Mahasiswa (BEM) Universitas Islam Riau menjelaskan bahwa pada dasarnya setiap aksi demonstrasi mahasiswa dimulai dari niat untuk kebaikan bersama dengan cara menyikapi kebijakan yang tidak sesuai aspirasi masyarakat". ${ }^{20}$

Dalam pengamatan penulis bahwa sebagian besar aksi demonstrasi mahasiswa berjalan tertib, sedangkan sebagian kecil aksi demonstrasi mahasiswa menyalahi aturan yang berlaku. Kenyataan ini terjadi karena kesalahpahaman antara demonstran dengan pihak keamanan, adanya provokasi, karena adanya intervensi, dan sebagainya. Penulis berpendapat bahwa sebaiknya pihak keamanan yang bertanggung jawab atas keamanan pelaksanaan demonstrasi harus mengantisipasi kemungkinan aksi yang dilakukan di luar prosedur yang berlaku.

Raja Kosmos Parmulais, Kaur Bin Ops Sat Intelkam Polresta Pekanbaru berpendapat bahwa "mahasiswa yang akan melakukan demonstrasi wajib memberikan kegiatannya ke pihak kepolisian dalam waktu $3 \times 24$ jam. Tujuannya untuk mengetahui mengenai bentuk kegiatan, tujuan, alat yang digunakan, jumlah massa, dan siapa koordinator lapangan. Dalam pelaksanaan demonstrasi mahasiswa tidak memahami aturan-aturan tersebut seperti tidak melaksanakan demonstrasi pada hari libur, tidak melaksanakan demonstrasi di tempat objek vital, fasilitas umum, seperti Bandara, Rumah Sakit, Wilayah Otoritas Militer, dan lainlain". ${ }^{21}$ Mahasiswa yang akan melaksanakan demonstrasi harus memperhatikan ketertiban umum. Demonstrasi yang dilaksanakan oleh

\footnotetext{
${ }^{17}$ Hasil wawancara dengan Hotman Sitompul pada 6 Mei 2015 di kantor DPRD Kota Pekanbaru.

18 Jonny Sinaga, Kewajiban Negara Dalam ICCPR, Jurnal Hak Asasi Manusia, Volume 4, Nomor 4, Tahun 2007, hlm. 201.

${ }^{19 H a s i l ~ w a w a n c a r a ~ d e n g a n ~ A l i ~ A k b a r ~ S i r e g a r, ~ P r e s i d e n ~ M a h a s i s w a ~ U n i v e r s i t a s ~ L a n c a n g ~ K u n i n g ~ p a d a ~}$ hari Jum'at, tanggal 01 Mei 2015, jam 14.00 Wib, di Kantor Badan Eksekutif Mahasiswa (BEM).

${ }^{20}$ Hasil wawancara Muhammad Syarif pada hari Jum'at, tanggal 08 Mei 2015, jam $15.00 \mathrm{Wib}$, di Kantor BEM Universitas Islam Riau.

${ }^{21}$ Hasil wawancara dengan Raja Kosmos Parmulais pada hari Rabu, tanggal 06 Mei 2015, jam 14.00 WIB di Polresta Pekanbaru.
} 
mahasiswa semestinya berjalan tertib dan lancar. ${ }^{22}$

Menurut Ali Akbar Siregar menyatakan bahwa "terkadang demonstrasi menjadi kericuhan karena adanya oknum dari pihak kepolisian yang tidak menghargai aksi demonstrasi mahasiswa atau tidak memahami Undang-Undang Nomor 9 Tahun 1998 tentang Kemerdekaan Menyampaikan Pendapat di Muka Umum". ${ }^{23}$ Sementara itu, Muhammad Syarif menjelaskan bahwa "demonstrasi anarkis terjadi karena beberapa hal, yakni pejabat yang berwenang tidak menerima massa aksi demonstrasi, pihak keamanan bertindak berlebihan, provokasi dan intervensi, dan mahasiswa bersikeras terhadap tuntutannya, sehingga terjadi adu mulut antara mahasiswa dengan pihak keamanan". ${ }^{24}$

Demonstrasi yang dilaksanakan oleh mahasiswa cenderung kurang memperhatikan ketentuan hukum yang berlaku. Dalam pelaksanaan demonstrasi terkadang mahasiswa melakukan pemblokiran jalan yang menimbukan kemacetan. Selanjutnya, mahasiswa berorasi dengan mengeluarkan perkataan yang menghina aparatur negara, meskpun hal ini relatif kecil. Selain itu, demonstrasi yang dilaksanakan pernah satu kali berakhir tidak tertib (anarkis), yakni pada tahun 2014. Pada waktu itu, mahasiswa melakukan demonstrasi penolakan kunjungan Presiden Jokowi ke Pekanbaru. Saat itu, mahasiswa berdemonstrasi di Jalan Sudirman, tepatnya gedung Radio Republik Indonesia (RRI) Pekanbaru. Ketika itu, terjadi bentrokan antara demonstran dengan aparat keamanan (polisi).

Kenyataan di atas disesalkan oleh Said Firdaus menerangkan bahwa "peristiwa tersebut terjadi karena ada provokator yang memprovokasi mahasiswa". ${ }^{25}$ Pernyataan senada juga disampaikan oleh Mella selaku Kabid Organisasi dan Politik Universitas Riau yang menyatakan bahwa "seharusnya pihak kepolisian bisa menahan diri saat mengamankan aksi demonstrasi mahasiswa" ${ }^{26}$ Ali Akbar Siregar menilai demonstrasi yang dilaksanakan oleh mahasiswa belum dilaksanakan dengan prosedur dalam Undang-Undang Nomor 9 Tahun 1998 tentang Kemerdekaan Menyampaikan Pendapat di Muka Umum. Jika dilaksanakan sesuai prosedur tentu tidak ada aksi-aksi demonstrasi yang menjurus anarkis. ${ }^{27}$

Said Firdaus mencermati bahwa Undang-Undang Nomor 9 Tahun 1998 belum berjalan efektif. Menurutnya, "mahasiswa yang melakukan aksi demonstrasi pernah mendapat kesulitan dari pihak kepolisian. Pihak kepolisan melarang aksi demonstrasi mahasiswa hanya karena ingin mengamankan lokasi. Hal ini jelas

\footnotetext{
${ }^{22}$ Hasil wawancara Muhammad Syarif pada hari Jum,at, tanggal 08 Mei 2015, jam 15.00 Wib, di Kantor BEM Universitas Islam Riau.

${ }^{23}$ Hasil wawancara dengan Ali Akbar Siregar, Presiden Mahasiswa Universitas Lancang Kuning pada hari Jum'at, tanggal 01 Mei 2015, jam 14.00 Wib, di Kantor Badan Eksekutif Mahasiswa (BEM).

${ }^{24}$ Hasil wawancara Muhammad Syarif pada hari Jum'at, tanggal 08 Mei 2015, jam 15.00 Wib, di Kantor BEM Universitas Islam Riau.

${ }^{25}$ Hasil wawancara dengan Said Firdaus, Menteri Sosial dan Politik Badan Eksekutif Mahasiswa (BEM) Universitas Islam Negeri Sultan Syarif Kasim Pekanbaru pada hari Senin, tanggal 4 Mei 2015, jam 9.00 Wib, di kantor BEM Universitas Islam Negeri Sultan Syarif Kasim Pekanbaru.

${ }^{26}$ Hasil wawancara dengan Mella Kabid Organisasi dan Politik Universitas Riau pada hari Rabu, tanggal 29 April 2015, jam 11.00 Wib, di Kantor BEM Universitas Riau.

${ }^{27}$ Hasil wawancara dengan Ali Akbar Siregar, Presiden Mahasiswa Universitas Lancang Kuning pada hari Jum'at, tanggal 01 Mei 2015, jam 14.00 Wib, di Kantor Badan Eksekutif Mahasiswa (BEM).
} 
mahasiswa mengalami kesulitan untuk menyampaikan pendapat di muka umum". ${ }^{28}$ Muhammad Syarif menjelaskan bentuk-bentuk kesulitan untuk melaksanakan demonstrasi. "Pertama, pengurusan surat izin demonstrasi sulit keluar dari pihak kepolisian. Persyaratan izin demonstrasi memberatkan dan pengurusan izin dipersulit. Kedua, adanya intervensi baik dari pihak intelijen maupun pihak tertentu yang tidak menginginkan adanya aksi demonstrasi. Selain itu, ada ancaman terhadap rencana aksi demonstrasi, bahkan penculikan terhadap demonstran yang akan melaksanakan aksi demonstrasi". ${ }^{29}$

\section{Hambatan Pelaksanaan Demonstrasi Mahasiswa Kota Pekanbaru}

Pelaksanaan demonstrasi mahasiswa di Kota Pekanbaru berdasarkan Undang-Undang Nomor 9 Tahun 1998 tentang Kemerdekaan Menyampaikan Pendapat di Muka Umum terdapat beberapa hambatan. Hambatanhambatan itu diantaranya: Pertama, pembatasan waktu aksi demonstrasi. Kedua, tanggung jawab keamanan aksi demonstrasi belum dilaksanakan dengan baik dan benar. Ketiga, pihak keamanan yang terlalu keras. ${ }^{30}$

Ali Akbar Siregar mengemukakan bahwa "adanya pembatasan waktu untuk berdemonstrasi menjadi pemicu timbulnya demonstrasi yang tidak tertib. Ditambah lagi masih banyak oknum kepolisian yang tidak memahami Undang-Undang Nomor 9 Tahun 1998 tentang Kemerdekaan Menyampaikan Pendapat di Muka Umum". 31

Raja Kosmos Parmulais tidak sependapat dengan pandangan tersebut. Menurutnya, "sebagian besar koordinator lapangan (korlap) aksi demonstrasi tidak mengikuti aturan pelaporan rencana aksi, sehingga polisi tidak menerbitkan izin demonstrasi. Seringkali mahasiswa beranggapan bahwa setelah memberikan surat pemberitahuan dalam jangka waktu $1 \times 12$ jam sebelum pelaksanaannya maka kewajibannya sudah terpenuhi. Dalam pelaksanaan demonstrasi korlap harus menjaga agar aksi demonstrasi berjalan tertib dan tidak anarkis". ${ }^{32}$

Dalam hal tanggung jawab keamanan aksi demonstrasi tampaknya belum dilaksanakan dengan baik dan benar. Said Firdaus menilai pihak kepolisian belum sepenuhnya melaksanakan tanggung jawab penyelenggaraan keamanan aksi demonstrasi mahasiswa dengan baik dan benar. ${ }^{33}$

Setahun yang lalu terjadi insiden bentrokan antara mahasiswa dengan pihak kepolisian di kantor Radio Republik Indonesia (RRI). Menurut Muhammad Syarif, "pihak

\footnotetext{
${ }^{28}$ Hasil wawancara dengan Said Firdaus, Menteri Sosial dan Politik Badan Eksekutif Mahasiswa (BEM) Universitas Islam Negeri Sultan Syarif Kasim Pekanbaru pada hari Senin, tanggal 4 Mei 2015, jam 9.00 Wib, di kantor BEM Universitas Islam Negeri Sultan Syarif Kasim Pekanbaru.

${ }^{29}$ Hasil wawancara Muhammad Syarif pada hari Jum'at, tanggal 08 Mei 2015, jam 15.00 Wib, di Kantor BEM Universitas Islam Riau.

${ }^{30}$ Ketiga hambatan di atas merupakan hasil analisis penulis dalam penelitian lapangan dan penyataan beberapa responden yang diwawancarai dalam penelitian.

${ }^{31}$ Hasil wawancara dengan Ali Akbar Siregar, Presiden Mahasiswa Universitas Lancang Kuning pada hari Jum'at, tanggal 01 Mei 2015, jam 14.00 Wib, di Kantor Badan Eksekutif Mahasiswa (BEM).

${ }^{32}$ Hasil wawancara dengan Raja Kosmos Parmulais pada hari Rabu, tanggal 06 Mei 2015, jam 14.00 WIB di Polresta Pekanbaru.

${ }^{33}$ Hasil wawancara dengan Said Firdaus, Menteri Sosial dan Politik Badan Eksekutif Mahasiswa (BEM) Universitas Islam Negeri Sultan Syarif Kasim Pekanbaru pada hari Senin, tanggal 4 Mei 2015, jam 9.00 Wib, di kantor BEM Universitas Islam Negeri Sultan Syarif Kasim Pekanbaru.
} 
kepolisian memang telah bertanggung jawab melakukan pengamanan. Namun, pengamanan yang dilakukan oleh pihak kepolisian belum tepat dan belum sesuai dengan yang seharusnya. Bahkan pihak kepolisian terkadang melakukan intervensi atau pengancaman, seperti dengan cara telepon, sms, atau bertemu langsung. Selain itu, pengamanan yang dilakukan oleh pihak kepolisian berlebihan". ${ }^{34}$

Insiden bentrokan antara mahasiswa dengan pihak kepolisian, terbukti adanya oknum polisi yang melakukan pemukulan dengan alat pentungan terhadap massa aksi demonstrasi mahasiswa. Padahal, massa aksi demonstrasi mahasiswa tidak memiliki senjata. Bahkan terdapat oknum polisi memukul dan mengusir mahasiswa yang sedang sholat di Musholla kantor Radio Republik Indonesia (RRI) Pekanbaru.

Hambatan lain yang ditemukan adalah pihak keamanan yang terlalu keras. Menurut Muhammad Syarif, "intervensi dari pihak keamanan atau intelijen, provokasi, pejabat atau sasaran aksi menghilang, kesalahpahaman antar massa aksi demonstrasi dengan pihak keamanan, sehingga mengakibatkan konflik fisik, pengamanan aksi yang kasar, penghancuran/penyitaan/perampasan alat peraga aksi, seperti toa, speaker, dan pengamanan dengan cara kasar yang tidak bertanggung jawab". ${ }^{35}$

Asril Darma memahami adanya berbagai keluhan dari aktivis mahasiswa tersebut. Menurutnya, "mahasiswa kecewa kepada pihak kepolisian karena terlalu keras dalam menangani aksi demonstrasi mahasiswa, misalnya aksi demonstrasi mahasiswa saat menyambut kunjungan Presiden Republik Indonesia Joko Widodo beberapa waktu yang lalu. Saat itu, mahasiswa melakukan aksi demonstrasi karena Presiden Joko Widodo menaikan harga Bahan bakar Minyak (BBM) di Indonesia". ${ }^{36}$

\section{Upaya Mengatasi Hambatan Pelaksanaan Demonstrasi Mahasiswa Kota Pekanbaru Dintinjau Dari Undang-Undang Nomor 9 Tahun 1998 tentang Kemerdekaan Menyampaikan Pendapat di Muka Umum}

Terdapat beberapa upaya yang harus dilakukan untuk mengatasi hambatan pelaksanaan demonstrasi mahasiswa Kota Pekanbaru. Pertama, peningkatan pemahaman mahasiswa mengenai Undang-Undang Nomor 9 Tahun 1998 tentang Kemerdekaan Menyampaikan Pendapat di Muka Umum. Kedua, peningkatan pengamanan yang dilakukan pihak kepolisian. Ketiga, pendanaan yang mencukupi. Keempat, penerapan aturan hukum yang jelas dan mengikat. Kelima, koordinasi dan komunikasi yang intens antara mahasiswa, kepolisian, dan pemerintahan.

Upaya yang pertama adalah peningkatan pemahaman mahasiswa mengenai UndangUndang Nomor 9 Tahun 1998 tentang Kemerdekaan Menyampaikan Pendapat di Muka Umum. Menurut Asril Darma, "semua pihak yang terkait, seperti Kesbangpol, Kepolisian, DPRD Kota Pekanbaru, dan instansi lainnya, dapat mensosialisasikan Undang-Undang Nomor 9 Tahun 1998 kepada

\footnotetext{
${ }^{34}$ Hasil wawancara Muhammad Syarif pada hari Jum'at, tanggal 08 Mei 2015, jam 15.00 Wib, di Kantor BEM Universitas Islam Riau.

${ }^{35} \mathrm{Ibid}$.

${ }^{36}$ Hasil wawancara dengan Ketua Persatuan Wartawan Indonesia (PWI) Kota Pekanbaru pada hari Senin, tanggal 11 Mei 2015, jam 10.00 Wib, di Kantor PWI Kota Pekanbaru.
} 
kelompok-kelompok yang berpotensi menggelar unjuk rasa, seperti mahasiswa, buruh, dan sebagainya" ${ }^{37}$

Hotman Sitompul menjelaskan perlunya sosialisasi kepada mahasiswa secara berkesinambungan mengenai Undang-Undang Nomor 9 Tahun 1998. Tujuannya agar pemahaman mahasiswa meningkat mengenai substansi yang terdapat dalam UndangUndang Nomor 9 Tahun 1998 tentang Kemerdekaan Menyampaikan Pendapat di Muka Umum. ${ }^{38}$

Said Firdaus setuju dengan berpendapat tersebut. Menurut Said Firdaus, "mahasiswa yang akan melaksanakan demonstrasi mesti memahami Undang-Undang Nomor 9 Tahun 1998 tentang Kemerdekaan Menyampaikan Pendapat di Muka Umum. Tujuannya agar pelaksanaan demonstrasi berjalan dengan tertib dan teratur" ${ }^{39}$

Upaya yang kedua adalah peningkatan pengamanan yang dilakukan pihak kepolisian. Berkenaan dengan pengamanan yang dilakukan pihak kepolisian, Said Firdaus bahwa dalam rangka mengamankan aksi demonstrasi mahasiswa, pihak kepolisian harus mengawasi demonstrasi dan kondisi massa. ${ }^{40}$

Upaya yang ketiga adalah pendanaan yang mencukupi. Raja Kosmos Parmulias berpendapat bahwa "setiap pengamanan membutuhkan dana yang mencukupi. Selama ini dana operasional pengamanan aksi demonstrasi belum mencukupi. Oleh karena itu, perlu dukungan anggaran yang optimal setiap pelaksanaan pengamanan demonstrasi" ${ }^{41}$

Upaya yang keempat adalah penerapan aturan hukum yang jelas dan mengikat. Raja Kosmos Parmulias berpendapat bahwa "perlu adanya aturan hukum yang jelas dan mengikat bagi demonstrasi yang tidak memiliki izin. Di samping itu, perlu adanya sanksi pidana terhadap aksi demonstrasi mahasiswa yang bertindak melanggar ketentuan hukum yang berlaku. Mahasiswa harus mengikuti normanorma hukum yang berlaku dan menaatinya. Tujuannya agar demonstrasi berjalan dengan aman dan tidak anarkis". ${ }^{42}$

Upaya yang kelima adalah koordinasi dan komunikasi yang intens antara mahasiswa dengan kepolisian. Raja Kosmos Parmulias menjelaskan bahwa "Korlap perlu berkoordinasi secara terbuka dengan pihak kepolisian mengenai jumlah massa, alat yang dibawa, dan tujuan demonstrasi, dan melakukan kerja sama yang baik dengan instansi pemerintahan". ${ }^{43}$

Dalam melaksanakan demonstrasi mahasiswa harus menyampaikan tujuan demonstrasi dengan baik kepada sasarannya. Muhammad Syarif menjelaskan bahwa "perlu terjalin koordinasi dan komunikasi yang intens antara pihak mahasiswa dengan pihak kepolisian, membiasakan diri untuk tertib melaksanakan demonstrasi memperbaiki

${ }^{37}$ Ibid.

${ }^{38}$ Hasil wawancara dengan Hotman Sitompul pada 6 Mei 2015 di kantor DPRD Kota Pekanbaru.

${ }^{39}$ Hasil wawancara dengan Said Firdaus, Menteri Sosial dan Politik Badan Eksekutif Mahasiswa (BEM) Universitas Islam Negeri Sultan Syarif Kasim Pekanbaru pada hari Senin, tanggal 4 Mei 2015, jam 9.00 Wib, di kantor BEM Universitas Islam Negeri Sultan Syarif Kasim Pekanbaru.

${ }^{40}$ lbid.

${ }^{41}$ Hasil wawancara dengan Raja Kosmos Parmulais pada hari Rabu, tanggal 06 Mei 2015, jam 14.00 WIB di Polresta Pekanbaru.

${ }^{42}$ Ibid.

${ }^{43}$ Ibid. 
manajemen aksi, menajemen konflik, dan halhal lainnya yang bersifat mendukung, menjalankan teknik lapangan (teklap) dengan baik, memfungsikan koodinator umum (kordum), korlap, dan struktur aksi dengan baik, dan mempersiapkan kepribadian yang kreatif, inovatif, dan menjunjung tinggi peraturan yang berlaku" ${ }^{44}$

\section{Kesimpulan}

Berdasarkan analisis dalam pembahasan di atas dapat disimpulkan sebagai berikut:

1. Ketertiban mahasiswa berdemonstrasi di Kota Pekanbaru belum berjalan efektif menurut Undang-Undang Nomor 9 Tahun 1998 tentang Kebebasan Menyampaikan Pendapat di Muka Umum. Mahasiswa cenderung tidak memberitahukan rencana aksi demonstrasi kepada pihak kepolisian, aksi demonstrasi mahasiswa melebihi batas waktu yang ditentukan peraturan perundang-undangan yang berlaku, aksi demonstrasi mahasiswa berubah tidak tertib dan cenderung anarkis, dan sebagainya.

2. Hambatan yang dihadapi dalam pelaksanaan demonstrasi karena adanya pembatasan waktu dalam menyampaikan pendapat di muka umum, aksi demonstrasi tidak mengikuti aturan pelaporan rencana aksi, pengamanan yang kasar yang tidak bertanggung jawab, intervensi dari pihak keamanan terutama intelijen, provokasi, pejabat atau sasaran aksi menghilang, kesalahpahaman antar massa aksi demonstrasi dengan pihak keamanan sehingga mengakibatkan konflik fisik, pengamanan aksi yang kasar, dan peng- hancuran/penyitaan/perampasan alat peraga aksi, seperti toa dan speaker.

3. Upaya yang harus dilakukan dalam mengatasi beberapa hambatan itu adalah sosialisasi atau penyuluhan hukum Undang-Undang Nomor 9 Tahun 1998 tentang Kebebasan Menyampaikan Pendapat Di Muka Umum kepada mahasiswa di Kota Pekanbaru agar mereka memahami substansi peraturan tersebut, pihak kepolisian harus memahami kondisi demonstrasi mahasiswa, pendanaan yang mencukupi, dan aturan hukum yang jelas dan mengikat.

\section{Saran}

1. Sebaiknya mahasiswa di Kota Pekanbaru yang akan berdemonstrasi dan pihak kepolisian yang bertugas mengamankan harus memahami substansi UndangUndang Nomor 9 Tahun 1998 tentang Kebebasan Menyampaikan Pendapat di Muka Umum agar demonstrasi dapat berjalan tertib.

2. Sebaiknya mahasiswa di Kota Pekanbaru yang akan berdemonstrasi tetap konsisten mengikuti aturan pelaporan rencana aksi dan tidak melakukan anarkis, sebaliknya pihak kepolisian dalam mengamankan tidak kasar, tidak melakukan intervensi, dan tidak memprovokasi.

3. Terkait dengan upaya yang harus dilakukan dalam mengatasi beberapa hambatan maka setiap pengurus organisasi mahasiswa mensosialisasikan Undang-Undang Nomor 9 Tahun 1998 tentang Kebebasan Menyampaikan Pendapat Di Muka Umum kepada setiap kadernya.

${ }^{44}$ Hasil wawancara Muhammad Syarif pada hari Jum'at, tanggal 08 Meil 2015, jam 15.00 Wib, di Kantor BEM Universitas Islam Riau. 


\section{Referensi}

Anugrah Purnamasari S. Kajian Spasial Ruang Publik (Public Space) Perkotaan Untuk Aktivitas Demonstrasi Mahasiswa di Kota Makassar, Jurnal Bumi Indonesia. Volume 1. Nomor 2. Tahun 2012.

Badan Pengembangan dan Pembinaan Bahasa. 2007. Kamus Besar Bahasa Indonesia. Jakarta: Balai Pustaka.

Daniel Simamora. 2010. Analisis Pertanggungjawaban Pidana Pelaku Unjuk Rasa yang Bersifat Anarki (Studi Putusan Nomor: 2.156/Pid.B/2009/ PN.Mdn). Medan: Universitas Sumatera Utara.

Darwan Prinst. 2001. Sosialisasi \& Diseminasi Penegakan Hak Asasi Manusia. Bandung: Citra Aditya Bakti.

Eric Hoffer. 1992. Gerakan Massa. ter. Masri Maris. Jakarta: Yayasan Obor Indonesia.

I Gede Pasek Eka Wisanjaya. Hak Menyatakan Pendapat di Muka Umum Secara Bebas dan Bertanggungjawab. Jurnal
Hukum Udayana. Volume 2. Nomor 1. 2013.

Jonny Sinaga. Kewajiban Negara Dalam ICCPR. Jurnal Hak Asasi Manusia. Volume 4. Nomor 4. Tahun 2007.

Muhammad Gazali Rahman.Unjuk Rasa Versus Menghujat (Analisis Deskiptif Melalui Pendekatan Hukum Islam. Jurnal Studia Islamika. Volume 12. Nomor 2. Desember 2015.

N.J. Smelser. 2000. Theory of Collective Behaviour. Jakarta: Yayasan Obor Indonesia.

Sri Handayani. 2008. Implementasi UndangUndang Nomor 9Tahun 1998 tentang Kemerdekaan Menyampaikan Pendapat di Muka Umum di Wilayah Sragen. Surakarta: Tesis Pascasarjana IImu Hukum Universitas Sebelas Maret.

Tri Pranadji. Aksi Unjuk Rasa (dan Radikalisme) Serta Penangannya Dalam Alam Demokrasi di Indonesia, Jurnal Forum Penelitian Agro Ekonomi. Volume 26. Nomor 2. Desember 2008. 